\title{
So Many Refusals: Northern/Southern Perspectives on Current Issues of Refugee Protection
}

\author{
Michael Bossin
}

\begin{abstract}
This paper provides a general overview of the global situation regarding refugees. Specifically, the paper focuses on current trends affecting refugees, and the responses of the developed and developing worlds to those issues. Restrictive measures in the north, designed to limit the numbers of asylum seekers in developed countries, correspond with a decrease in security for refugees in the south. It is suggested that there are clear linkages between the two situations.
\end{abstract}

\section{Résumé}

Cet article fournit un aperçu général de la situation globale des réfugiés. Plus particulièrement, on $y$ analyse les tendances fondamentales qui affectent les réfugiés, et les réponses apportées par lemonde développéet le monde en développement à ces questions. Les mesures restrictives au Nord, conçues pour limiter lenombre de demandeurs d'asile dans les pays développés, sont concomitantes à un net déclin des conditions de sécurité pour les réfugiés auSud. Ilest avancé ici qu'un lien certain est à établir entre ces deux situations.

The human rights organization, Amnesty International, recently conducted a review of its work with refugees. The report begins with a quotation from a Mauritanian refugee in Senegal. She says:

Michael Bossin is an immigration/refugee lawyer and lectures at the University of Ottawa. He is currently the vice-president of Amnesty International Canada's Englishspeaking branch.
As a refugee you live a life hearing no - no you cannot stay in your own home; no you cannot come into this country; no you cannot stay; no I cannot help; no I don't have time. So many refusals. You lose your dignity. I know Amnesty cannot be the one to say yes, but at least it is a place where we are able to hear: we are with you, we are trying, we will do our best. That offers hope and hope sustains our dignity. ${ }^{1}$

The comment can be taken as praise for the human rights organization and, by extension, other non-governmental agencies which have advocated for the rights of refugees and encouraged and lobbied governments to uphold their obligations towards displaced people. Regrettably, it is also illustrative of the frosty reception refugees increasingly face in the nineties by countries around the world. "So many refusals".

This afternoon, I have been asked to speak about current issues affecting refugees and specifically, the responses to those issues in the industrialized world and in the less developed world - in the north and in the south. ${ }^{2}$ This is simply an overview, meant to leave you with a general idea of what "the big picture" entails. Hopefully, it will provide a context to that remark, "So many refusals".

I shall begin by identifying several issues, or trends, which have affected and continue to affect refugees in the past decade. Afterwards, we shall examine some governmental responses to those issues and trends.

\section{Current Issues/Trends- The Numbers}

In its report, The State of the World's Refugees, 1997-98, the United Nations High Commissioner for Refugees (hereinafter "the UNHCR") notes:
While it may be an age-old problem, the issue of forced displacement has assumed some particularly important - and in several senses new dimensions in the final years of the $20^{\text {th }}$ century. First and foremost, the numbers have been staggering. ${ }^{3}$

In 1998, the UNHCR estimated that some 50 million people around the world might legitimately be described as victims of forced displacement. ${ }^{4}$ That is almost double the population of Canada.

It is true that in some parts of the world, the number of refugees has decreased in the past decade. This is the case in Africa, Asia and Latin America. ${ }^{5}$ However, one should be cautious in labelling this a trend. While the numbers have gone down in these regions, in Europe, the number of refugees has increased dramatically. ${ }^{6}$ Also, refugee flows develop as a response to a particular crisis or situation and therefore fluctuate with the times. The "trend" of decreasing numbers in Africa, for example, could be reversed tomorrow. Moreover, even if reduced from levels of 10 years ago, the numbers are still extremely large.?

One should be clear that the figure of 50 million is not comprised solely of refugees as defined by the 1951 UN Refugee Convention, ${ }^{8}$ those who are outside their country of nationality. A significant proportion of the estimated 50 million are people displaced within their own borders.

Regardless of their legal status, all displaced persons place a demand on the world for some type of humanitarian response. The cost of housing, feeding and in other ways accommodating the displaced is affected by the high numbers. Moreover, that cost extends beyond what can be quantified in dollars. For the host countries and regions, there is a price to be paid in environmental, 
social and political terms as well. Today, people forced to flee are greeted not only with compassion, but with a measure of anxiety and resentment as well. The level and quality of each response, one could argue, is partly contingent on the numbers arriving.

\section{Changing Profile}

One important factor affecting human rights and refugee protection in the past ten years has been the end of the Cold War and the collapse of the Soviet Union. Until that dissolution, tension between the Soviet bloc and Western countries provided a constant, significantbackdrop to issues of refugeedetermination.

The Convention definition itself was influenced by East-West conflict. Explains commentator James Hathaway, the Convention refugee definition was "carefully phrased to include only persons who have been disenfranchised by their state on the basis of race, religion, nationality, membership in a particular social group, or political opinion, matters in regard to which Eastbloc practice [had] historically been problematic." In other words, for the West in particular, during the Cold War, there was always a political incentive for granting asylum to people escaping from East bloc countries. With the collapse of the USSR and other Communist regimes, that incentive has diminished. ${ }^{10}$

Another consequence of the end of the Cold War is that these days, there are fewer "traditional" refugees - persons escaping specific and relatively individualized forms of punishment. ${ }^{11}$ Ten years ago, the profile of the asylum seeker was often that of an individual targeted forhis or her political activities, students and intellectuals fleeing dictatorships in Latin America, or dissidents escaping Soviet bloc countries for having expressed anti-government views. ${ }^{12}$

Refugees in this decade are more likely to have fled from their countries en masse, from recent human rights disasters such as Somalia or Rwanda. Such migrations are large in number and occur over a relatively short period of time.
Since the collapse of the Soviet Union, there has been a dramatic increase in ethnic-based violence. In a number of instances, depopulation of an ethnic minority from a region has become an objective of the majority, and not just a consequence of the violence. Hundreds of thousands have been forcibly expelled ("ethnically cleansed")from Bosnia, Kosovo and the Caucasus states of the former Soviet Union in this manner on account of their ethnic identity. Left behind is an "ethnically pure" population, sympathetic to the ruling power.

Finally, as a result of the changing political landscape, and, in part, the lifting of travel restrictions in former East bloc countries, asylum seekers are emerging from areas previously unaffected by refugee problems. The former Soviet Union and former Yugoslavia are obvious examples, butnew flows of refugees have also arisen in recent years: from Bhutan and Tibet crossing into Nepal; from Myanmar into Bangladesh and Thailand; and from Bhutan, Sri Lanka and Tibet into India. ${ }^{13}$

\section{Internally Displaced Persons}

There has been a dramatic increase in the number of internally displaced people in the world. These are people who have been forcibly displaced and who remain, whether by necessity or choice, within their country of origin. In 1996, the UNHCR estimated that there were 34 countries in the world with internally displaced populations. This was up from 5 countries in $1970 .{ }^{14}$ The U.S. Committee for Refugees estimates that there are more than 20 million internally displaced people in the world today. ${ }^{15}$ The UNHCR figures are even higher, somewhere "in the region of 25 to 30 million." 16

The challenge of providing assistance to internally displaced persons is formidable, as access to such populations is limited, or impossible. Moreover, despite the substantial work of the UNSecretary General's Representative on the Internally Displaced, "those who remain displaced inside their own countries tend to falloutside of the internationalinstitutional framework of pro- tection and assistance." 17

Why is this happening? In part, the phenomenon of internally displaced persons is a reflection of the growing number of internal conflicts in the world. Also, in some cases, it reflects the emphasis on countries enforcing the "right of individuals to remain in their country". The enforcement of this "right" has prevented people from seeking asylum (another internationally recognized right), and forced people to remain against their will in unstable situations. ${ }^{18}$ In Bosnia and Sri Lanka, for example, the departure of people has been blocked by government or opposition forces wishing to maintain control over the civilian population. ${ }^{19}$

\section{Widening Gap Between the Rich and Poor}

Indirectly affecting refugee flows is the fact that the gap between the richest and the poorest countries in the world is widening. During the past three decades, the income differential between the richest $5^{\text {th }}$ of the world's population and the poorest $5^{\text {th }}$ has more than doubled. It has gone from $30: 1$ to $78: 1 .^{20}$

In the less developed regions, at least 89 countries now have lower per capita incomes than they had 10 years ago. According to the UNCHR:

Many of the world's poorer nations are now locked into a vicious circle of economic stagnation, environmental degradation and impoverishment, reinforced in some cases by rapid rates of population growth. ${ }^{21}$

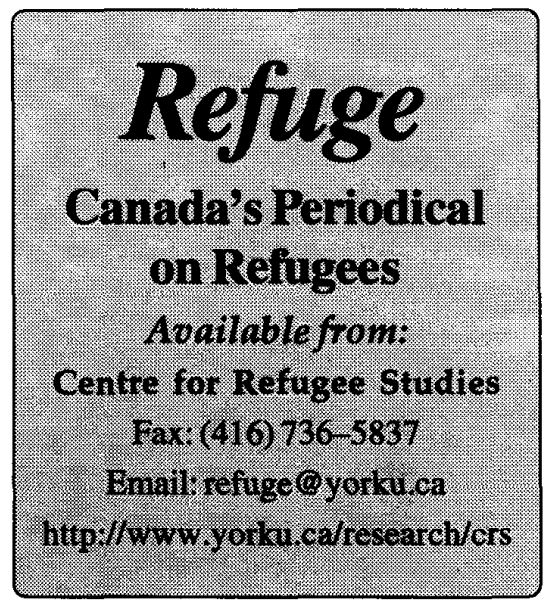

Refuge, Vol. 18, No.4 (November 1999) 
This combination of circumstances, of course, is a recipe for disaster. Although poverty and economic stagnation alone do not produce forced population displacements, they certainly create a climate for instability, repression, internal conflict and human rights abuses.

Clearly, this doesnothappen in every case. Lesotho, Namibia, Tanzania and Zambia are four examples of countries from southern Africa which, though very poor, have managed to avoid this type of situation. They, however, are the exception to the rule. "In general, there is ample evidence to demonstrate that countries with low and declining standards of living are particularly prone to complex emergencies, refugee outflows and other forms of forced displacement." 22

In addition to creating situations where people flee human rights abuses, this economic polarization also promptsindividuals to seekabetterlife elsewhere. Many of them, unable to reach that goal through "regular" or "legal" means, end up claiming to be refugees. $^{23}$

\section{The Phenomenon of Collapsing States}

In many parts of the world, Africa in particular, state structures have been greatly weakened, in some cases to the point of disintegration.

States withdraw from their traditional role of providing basic services, such as health, education and social welfare, and begin to lose their ability to perform some fundamental functions of the state, such as collecting taxes, paying officials and maintaining law and order. When this happens, people turn to other "structures" for security - the clan, for example, or other types of communal associations. This, in turn, reinforces the potential for internal social and political conflict. In the extreme cases - Afghanistan, Burundi, Liberia, Sierra Leone, Somalia - the political link between the state and its citizens is severely ruptured. In essence, the state simply dissolves. ${ }^{24}$ Clearly, where state structures disintegrate, forced population displacements are likely to ensue.

\section{Non-State Actors}

The most obvious form of persecution is the abuse of human rights by organs of the state, such as the police or military. ${ }^{25}$ Ten years ago, the majority of refugees were in fear of their own governments, which acted against them either directly or through persecuting groups or individuals who acted with the tacit approval of governments. Today, the agent of persecution is equally likely to be a non-governmental entity - organized crime, armed militias, or even an individual, for example in cases of domestic violence or female genital mutilation. In such cases, the state is sometimes unwilling to provide protection to the person concerned. In others, however, the state, though willing to protect, is unable to do so effectively.The likelihood of non-state actors being involved in acts of persecution is particularly great, of course, where the state structure has collapsed.

\section{Response of Governments in the North/South}

Before beginning an analysis of how governments have responded to current refugee issues and trends, a few preliminary points should be made. First, policies and practices in northern and southern states are not simply a direct response to the trends which Ihave identified. It is more complicated than that. In fact, many of the programs in place today were initiated years ago, in response to different pressures.

Secondly, comparing the refugee situation in the developing world, as opposed to the industrialized north, is a bit like comparing apples with oranges. The overwhelming majority of refugees (roughly 90 per cent, according to a 1997 Amnesty International report) are to be found in the south. ${ }^{26}$

In the south, one sees massive movements of refugees. In the north, as a rule, one sees individual asylum seekers. ${ }^{27}$ In part, this is because of barriers to refugee migrations that have been established by the industrialized countries. In part, it is due to geography. That is, most of the political situations leading to the displacement of peoplearelocated in the south.

These factors, to a great extent, dictate different responses to different circumstances in the north as opposed to the south. That being said, there are linkages between the two regions with respect to refugees. Most refugeeclaimants in the developed world come from the developing world in the south. Many travel through othernorthern and southern states before reaching their final destination. As well, countries in the south rely on monies from the north toeffectively deal with the inflow of refugees to their territory. Finally, how each region deals with refugee flows is well known to the other and has an influence on each other's policies and practices in this regard.

\section{The North}

Over the past decade, countries in the developed world have introduced an array of measures designed to prevent or deter people from seeking asylum in their territories. These measures were prompted, in large part, by a perceived "crisis" in the industrialized world. In the 1980 s, there was a sharp increase in the number and severity of refugee movements around the world. ${ }^{28}$ The response to this development can be characterized as either panic or "compassion fatigue". ${ }^{29}$ Unless action was taken, states reasoned, they were at risk of being over-run by claimants. It was assumed that many of the asylum seekers were not genuine refugees. They were accused of abusing the system of refugee determination, 30 "jumping the queue" ahead of legitimate refugees and immigrants and, in general, taking advantage of the generosity of northern states.

Governments were also concerned about the growing number of refugee claimants arriving at their borders without proper identity documents, or without documents at all. Described as an "irregular movement" of people ${ }^{31}$, this phenomenon had implications for security and was perceived by some as a major abuse of the system.

With theincreased number of refugee claimants, the cost of processing claims, 
and providing housing, social services, and health care to the claimants, grew accordingly. In a time of budget austerity, and an environment of increasing xenophobia, governments in the north decided to take steps to substantially reduce the number of asylum seekers arriving at their borders.

\section{Restricting the Flow}

To reduce the flow of refugee claimants coming to their countries, governments in the industrialized states have adopted a number of measures in recent years. These include:

imposing visa restrictions on refugee-producing countries. ${ }^{32}$ To enter many northern countries, citizens of southern states require a visa authorizing such entry. Without the visa, airlines will not permit travellers to board their planes; imposing sanctions or fines on airlines and other carriers who transport people to northern states without proper documents; ;3 initiating pre-boarding checks at airports, to ensure that passengers boarding aircraft are in possession of proper documents, ${ }^{34}$ and in some cases, interdicting vessels at seas and turning them back. ${ }^{35}$

If a refugee claimant is able to make it all the way to a northern state, in spite of these obstacles, he or she is faced with other barriers. Examples are as follows:

1) In many cases, the claimant will be returned to a "safe third country" and made to claim refugee status there; ${ }^{36}$

2) In a number of countries, asylum seekers are routinely detained, ${ }^{37}$

3) In many jurisdictions, persons coming from so-called "safe countries of origin" are put into a fast track, designed to have their claims rejected promptly with little or no appeal following the negative decision; ${ }^{38}$

4) As well, northern countries have cut back on benefits and rights formerly accorded to persons going through the refugee determination process. Benefits which have been affected by such cuts include welfare, legal aid and health coverage. There have also been restrictions on the right to work and the right to study, ${ }^{39}$

5) Finally, in many countries, a very restrictive interpretation of the Convention refugee definition has been applied by decision-makers. Consequently, very few claimants are recognized as Convention refugees. ${ }^{40}$

It can be safely assumed that the combination of these measures has had the effect of discouraging people from seeking asylum and thereby reduced the number of refugee claimants in those countries where such measures have been imposed. In fact, since 1992, the total number of asylum applications submitted in the industrialized states has dropped significantly, ${ }^{41}$ while at the same time, the global scale of forced displacement has continued to grow. ${ }^{42}$ One could expand on almost all of the initiatives described above. Ishall restrict my comments to just a few.

\section{Visa Restrictions, Preboarding Inspections, and the Safe Third Country Rule}

Visa restrictions make it harder for people at risk to easily and quickly escape to safe countries. Simply purchasing a ticket and boarding a plane for a country which has imposed a visa restriction is not an option. Even if all routes to safety are not affected by their imposition, visa restrictions effectively reduce the possibilities for persons at risk.

Admittedly, a visa requirement can curtail a situation in which numerous unfounded asylum claims from a particular country are clogging a refugee determination system. It is submitted, however, that one should not be imposed on a country from which legitimate refugees are fleeing and where there is noevidence of large-scale abuse.

Pre-boarding inspections mean that many legitimate refugees, unable to obtain proper documentation due to the situation in their countries, or forced to travel on false documents to circumvent visa restrictions, are turned back at airports without ever having their refugee claims heard or determined. Countries involved in this practice appear more concerned with preventing undocumented arrivals in their territory than with ensuring refugee claimants are allowed access to a fair and proper determination procedure.

The "safe third country" rule has created the phenomenon of "refugees in orbit", orchain deportations, often with little regard had to whether the "safe" country is obliged to hear the refugee claim or has in place other proper safeguards to ensure that asylum seekers are not returned to countries where they are at risk. In other words, there is insufficient regard given to whether the receiving country is really "safe."

According the European Council on Refugees and Exiles, increasingly," persons in need of protection (are ending up) in Central, Eastern or Southern Europe ... where mechanisms of refugee protection and assistance are often less well developed." 43

As one example of this phenomenon, the UNHCR notes that in May 1997, "Lithuania and Belarus were negotiating a readmission agreement which would enable the return of asylum seekers from the former to the latter state, even though Belarus was not a signatory to the international refugeeconventions." 44

\section{Detention}

Here is a quotation from a Togolese refugee, a 17 year old girl:

The police sprayed gas into the room and shut the door... When the policeman ordered me to leave the room he hit me again with his stick, this time on the shoulder. I tried to stand up, but I slipped and fell to the ground. The officer then kicked me in the lower back. ${ }^{45}$

To those of you who have listened to refugees tell their stories, this type of incidentmay sound familiar. However, this is not a refugee's account of persecution in her country of origin. It is her account of how she was treated after she asked for asylum in the United States.

Detention of asylum seekers has increased dramatically in the past decade in Europe and especially in the United States. ${ }^{46}$ In Australia, refugee claimants who arrive without prior authori- 
5.

zation are automatically detained. ${ }^{47}$ In some countries detention lasts throughout the entire procedure. In others, it is restricted to claimants whose applications are considered "manifestly unfounded". 48

According to the UNHCRExecutive Committee, there are only four reasons for detaining an asylum seeker: to verify identity; to determine the elements of the claim; to deal with people who have used destroyed or fraudulent documents in order to mislead the authorities (as opposed to people who admit travelling on false documents for reasons related to theirfear of persecution); and to protec national security or public order. Any otherreason for detaining a refugee claimant is unacceptable. ${ }^{49}$

\section{Restriction of Benefits/Rights}

\section{Here is another story:}

Benedicte had been arrested at a memorial for her husband, who had been shot dead during an anti-government rally. In prison, she was repeatedly raped by guards. An older guard finally tookpity on her and smuggled her out in a sack.

She arrived in London by train, and then made her way to the Home Office, some miles away, where she applied for asylum. She was subsequently denied welfare payments on the grounds that she had not applied for asylum immediately on arrival.

A legal challenge was made to the Court of Appeal about the denial of welfare payments, which ruled in her favour. One of the judges stated:

A significant number of genuine asylum seekers now find themselves faced with a bleak choice: whether to remain here destitute and homeless until their claims are finally determined or whether instead to abandon their whether instead to abandon their
claims and return to face the very persecution they have fled.

The legal victory was short-lived. In July 1996, the British parliamen passed legislation denying welfare payments to all those who failed to apply for asylum immediately on aprival and to people appec arival and to peple appealing against rejection of their asylum claim. However, in October a new High Court ruling required local gov- ernment authorities to provide some assistance to asylum-seekers. In December, for the first time in 50 years, the Red Cross distributed food parcels in London. The recipients were destitute asylumseekers. $^{50}$

Refugee claims can take a long time to be processed - often several years during which the applicant is in a legal and social limbo. Denying applicants access to basic needs such as adequate food, shelter and medical care only aggravates their sense of insecurity and isolation.

Although social assistance and similarmatters are not addressed in the UN Refugee Convention, the denial of such benefits to asylum seekers is certainly contrary to the spirit of that document.

\section{Restrictive Interpretation of the} Refugee Definition

One last story, taken from a 1997 Amnesty International report on refugees:

Diabasan Natuba sought asylum in Germany after escaping from a Zairean prison, where she was tortured because she had been caught photocopying party materials. The German authorities rejected her claim on several grounds. They stated that Zaire's president does control the military and therefore torture by soldiers does not constitute state persecution. They asserted that she had committed a crime by photocopying documents, so her detention was legitimate. They said that the fact that she had travelled on

a borrowed passport undermined her credibility. Most extraordinary of all, they said that her story was not credible because many other Zaireans had recounted similar incidents. In mid-1996, she was sheltering in a church in Germany, terrified

of being deported back to Zaire. ${ }^{51}$

This is a prime example of the type of restrictive interpretation of the refugee definition, not to mention an ignorance concerning country conditions, which has led to similar refusals of legitimate claims. In this country, the Supreme Court of Canada has recognized that a well founded fear of persecution may exist where the agent of persecution is not the state, where the state is either unable or unwilling to offer protection to the person concerned, and where the ground(s) for persecution are one or more of those enumerated in the Convention definition. ${ }^{52}$ This interpretation of the refugee Convention, however, is

\section{PATHS TO EQUITY:}

\section{Cultural, Linguistic, and Racial Diversity in Canadian} Early Childhood Education

By Judith K. Bernhard, Marie Louise Lefebvre, Gyda Chud, and Rika Lange Toronto: York Lanes PressISBN 1-55014-277-1; 112 pages, size 8.5x11; \$18.95

Paths to Equity is based on an extensive nationwide study of 77 childcare centres in Montreal, Toronto, and Vancouver on the cultural, linguistic, and racial diversity in Canadian Early Childhood Education (ECE). The report presents the results this study on how the ECE system is responding to the increasing diversity of contemporary Canadian society.

In this ground-breaking study, the authors have addressed teachers' views on diversity in the education programs; parents' difficulties in collaborating within the current education system; teachers' difficulties in understanding many "ethnic" parents; desire of many parents for better communication with staff, preferably in their own languages, and for more information about their individual children, and chances for effective input; and the evidence of some continuing problems with racism, irrespective of the good intentions of centre staff. Paths to Equity will be of interest to ECE faculty, policymakers, centre supervisors and staff and others interested in the inclusion of diversity content in professional education programs. Available from:

Centre for Refugee Studies, Fax: (416) 736-5837• Email: refuge@yorku.ca not universally accepted. In many

Refuge, Vo1.18,No.4 (November 1999) 
countries, as in the example above, state involvement in the persecution is a prerequisite to a finding that the claimant is a Convention refugee. ${ }^{53}$ This leaves vulnerable those whose oppressors are non-governmental entities, including armed militias. Obviously, a requirement for direct stateinvolvement would also exclude anyone living in a collapsed state.

The other common ground for refusal of a refugee claim in many jurisdictions is the requirement that the asylum seeker be "singled-out" for persecution. Governments have relied on this principle to deny recognition to claimants coming from countries where the violence is generalized. According to the UNHCR, such a narrow interpretation was never the intention of those who drafted the 1951 UN Refugee Convention. ${ }^{54}$

\section{Consequences of Restrictive Measures}

In addition to reducing the numbers of asylum seekers in developed countries, the measures described above have had several other consequences. Rather than "resolving" the refugee problem, these measureshavemerely diverted the refugee flow elsewhere. Refugees are simply resurfacing in other parts of the world. For example, as of 1997, there were roughly 700,000 asylum seekers in the Commonwealth of Independent States (CIS), 500,000 of whom were in Russia.55

Although severalCIS countries, such as Estonia and Lithuania have ratified the 1951 UN Refugee Convention, and passed national legislation to implement a refugee determination procedure, the capacity to implement the legislation is limited. "As a result, asylum-seekers from outside the CIS region often lack protection, have no legal status, do not benefit from social welfare services and may not even have access to refugee determination procedures." 56 Notes Kathleen Newland, of the U.S. Committee for Refugees, "The increase in formal adherence (to the Refugee and other Conventions) stands in stark contrast to declining observance in practice." 57
The restrictive measures have also led to a boom in the smuggling business. According to the UNHCR:

There is now a growing consensus that the restrictive asylum practices introduced by many of the industrialized states have converted what was a relatively visible and quantifiable flow of asylum seekers into a covert movement of irregular migrants that is even more difficult for states to count and control. There is also widespread agreement that such irregular movements are increasingly arranged and organized by professional traffickers. ${ }^{58}$

Legitimate refugees, afraid that they willnotbeadmitted, or will bedetained, or will have their asylum claims rejected regardless of the merits of their case, are simply being snuck into countries illegally. Needless to say, involving themselves with smugglers also leaves them open to physical and economic exploitation and risk.

\section{Temporary Protection}

In 1992, the UN High Commissioner for Refugees urged states to grant temporary protection to refugee claimants from the former Yugoslavia. The idea was that once the war ended, and it was safe for them to do so, the asylum-seekers would be returned home. Around 15 states, mostly in Western Europe agreed to establish a program of temporary protection, benefitting more than half a million people. ${ }^{59}$ Those in danger were provided sanctuary. At the same time, host countries were relieved of the necessity of conducting individual determinations in each case. For these reasons, the temporary protection program was seen to be a success. In Canada, a similar scheme was implemented this year in the case of ethnic Albanians fleeing Kosovo, albeit on a much smaller scale than the European response to the crisis in Bosnia.

It is notclear whether the provision of temporary protection to large groups of refugee claimants is a trend of the future. With respect to Kosovar refugees from Macedonia, for example, Germany accepted 10,000 , in sharp contrast to the more than 350,000 former Yugoslavs who found protection there in the early 1990s. ${ }^{60}$

Whether or not they are implemented widely, temporary protection regimes should be applied with care and caution. Those with temporary status have fewer rights than those persons who have been recognized as refugees under the 1951 UN Refugee Convention. For example, they do not benefit from the prohibition against refoulement, which applies to Convention refugees. Their status can be removed by the government for more easily than is the case with Convention refugees. The UNHCR Handbook on Procedures and Criteria forDetermining RefugeeStatus states:

Once a person's status as a refugee has been determined, it is maintained unless he comes within the terms of one of the cessation clauses. ${ }^{61}$ This strict approach towards the determination of refugee status results from the need to provide refugees with the assurance that their status will not be subject to constant review in the light of temporary changes - not of a fundamental character - in the situation prevailing in their country of origin. ${ }^{62}$

Persons not recognized as refugees under the UN Refugee Convention are, in aword, more vulnerable to premature removal by governments sensitive to political and societal pressures. Where an individual recipient of temporary protection fears that he or she may still be at risk if returned home, an opportunity to make an asylum claim should always be available.

\section{The South: A History of Generosity}

In general, it can be said that many of the world's poorest nations have a remarkable record of hospitality towards refugees. Malawi, for example, a country of few natural resources, a serious shortage of land and a population of just under 8 million, hosted more than a million Mozambican refugees from the mid-1980s to the early 1990 s. $^{63}$ Similar acts of generosity have been recorded throughout most of Africa, which continues to accommodate more refugees than any other part of the world. ${ }^{64}$ 
South and South-West Asia also provide examples of generosity when it comes to refugees. Pakistan and Iran jointly accepted more than 5 million refugees throughout most of the eighties. India has been home to Tibetan refugees from China, Chakmas from Bangladesh and Tamils from Sri Lanka, not to mention refugees from Afghanistan, Bhutan and Myanmar. ${ }^{65}$

In South-East Asia, Thailand has been host to refugees from Cambodia, Laos, Myanmar and Vietnam. In the Americas, Mexico provided asylum to over 100,000 Guatemalans in the eighties and early nineties. ${ }^{66}$

\section{Declining Standards of Protection}

Recently there have been troubling signs that protection standards in southern countries, which traditionally have borne the brunt of refugee protection, are in decline. Several of these indicators of declining standards are described below.

\section{Closing of Borders/Refoulemenent}

In a number of instances, countries have closed their borders to asylum seekers. This occurred in Tajikistan, Uzbekistan and Pakistan in the latter half of 1996 , when Afghans fleeing the Taliban offensive were denied entry. That same year, Tanzania and Zaire closed their borders to Hutus fleeing from Burundi. 67

In other cases, countries have returned refugees to countries where they may be at risk. In 1996, Thailand denied asylum to refugees from Myanmar and then returned 900 Myanmar women and children to a particularly dangerous part of their homeland. ${ }^{68}$

\section{Decrease of Security in the Country of Asylum}

Admission to a country of asylum no longer brings with it a guarantee of safety. Refugees living in camps are often dependent on rations that are distributed by groups responsible for abuses back home. The local power structure in the country of origin is often replicated - as are the abuses. ${ }^{69}$
Many refugee camps around the world have become militarized and politicized. Boys and young men have been forcibly conscripted into armies and militias. Women and girls have been victims of sexual abuse and other kinds of violence. In urban areas, in some countries, refugees are routinely harassed and arbitrarily detained. ${ }^{70}$ None of these are necessarily new phenomena, but the prevalence and severity of such incidents is now a major cause of concern.

There are other trends worth noting. In some cases, repatriations are taking place not because conditions have becomesafein the refugees' homecountry, but because they have become too dangerous in the host country, or for political reasons. Repatriations in such circumstances have not been voluntary, but coerced. In the past few years, according to the U.S. Committee for Refugees, refugees have been forcibly repatriated from Iran (to Afghanistan and Azerbaijan), from Bangladesh (to Burma), from Thailand (to Burma and Cambodia), and from Tanzania and the Democratic Republic of Congo (to Rwanda). ${ }^{71}$

In other cases, refugees wanting to go home have been prevented from doing so because the militant groups controlling these populations thought that to let them go would be to their political and military disadvantage. This was the case, for example, with Rwandan refugees in Zaire and Tanzania and Tajik refugees in Afghanistan. ${ }^{72}$

\section{Links between the North and South}

Not surprisingly, the restrictive actions of the wealthy states towards refugees have had an effect and influence on countries with fewer resources. According to the UNCHR:

When the very countries responsible for establishing the international refugee regime begin to challenge its legal and ethical foundations, then it is hardly surprising that other states, especially those with far more pressing economic problems and much larger refugee populations, have decided to follow suit.
Increasingly, when low-income countries close their borders to refugees, they tend to justify their actions by referring to the precedents which have already been set by the more affluent states. "In the current situation, what country would keep its borders open?" asked a government minister in an African country when confronted with an impending refugee influx. "If this was a Western country," he continued, "it would have been well accepted." 73

In a similar vein, Kathleen Newland writes, "The demonstration of these [restrictive] actions by rich countries has made it easier for poorer countries to justify similar measures: to close their borders to arriving refugees, to push hard for premature repatriation, or to take matters into their own hands and forcibly return refugees." 74

Is it any wonder that some of the poorer countries are feeling resentful of their northern counterparts? They are expected to respect and observe standards that, from their perspective, the wealthier countries are ignoring or undermining.

Other developments have reinforced this attitude, notably a growing reluctance on the part of the north to subsidize the solutions to refugee-related problems arising in the south. Malawi is one example. After all the generosity shown towards Mozambican refugees by that country, Malawi is now faced with serious environmental problems: deforestation and soil erosion in the regions where the refugees lived. Now that the refugees are gone, Malawicannot get aid to address this problem. ${ }^{75}$

Understandably, situations like this leave poorer states wary of admitting large flows of refugees into their territory. Many donor states make it clear that they nolonger are prepared to support long-term refugee assistance programs in other parts of the world. They want solutions arrived at quickly, and cheaply. This situation is compounded by the worsening economies and the lowering of aid ingeneral to many of the world's poorer nations. A growing number of these states have decided that sustaining large refugee po- 
pulations is simply a luxury they can no longer afford. ${ }^{76}$

Xenophobia exists in the developing world as well as in the industrialized world. In both situations, politicians are ready to exploit the fears of the populace, and blame refugees for the country's ills. No doubt, refugees have an impact on a host country: increasing the level of competition for resources which are scarce already. The resources to which I refer arenot just food and water, but education, health care and jobs. As mentioned above, refugees can also have a negative impact on the environment of a host country. All of this can lead to resentment from the local populations, who often think - mistakenly - that those in the camps have it better.

Finally, as mentioned above, during the Cold War the superpowers supported countries hosting refugees for political reasons. Now that the cold war is over, and that support is gone, countries are more anxious to improve relations with countries in their own regions. As a consequence, although granting asylum ought to be seen as a humanitarian act, it is now perceived in some quarters as a political one. In other words, admitting refugees from a neighbouring state with whom an alliance has been built, may put that alliance in jeopardy. It is such considerations which explains Thailand's reluctance to admit refugees from Myanmar and Tanzania's eagerness to repatriate Rwandans. ${ }^{77}$

This, too, is an echo of what is happening in Europe. In 1997, for example, the European Union accepted a proposal from Spain which could make it impossible for the citizen of oneEU state to seek asylum in another. ${ }^{78}$

\section{Conclusion}

All in all, I have not painted a very rosy picture. That being said, perhaps Ihave presented it to the right group. For those involved in refugee protection, the world has presented you with a formidable challenge. So many refusals. The phrase can be seen not only from the point of view of the refugee, but from that of aid workers, decision makers, law- yers and others in the field. For each refusal there are hurdles to overcome, laws to change and minds to convince. The challenges are many, and I wish you every success in meeting them.

\section{Notes}

1. Neve, Alex. "Globally, Thoroughly and Effectively Protecting the Human Rights of Displaced Persons", (1999) Amnesty International, POL $33 / 08 / 98$, at 1 .

2. In this paper, "the north" or "northern states" refers to developed, industrialized states-specifically those in Europe, North America and Australia. "The south" or "southern states" refers to those countries which, relative to the "north" are developing or undeveloped states.

3. United Nations High Commissioner for Refugees. The State of the World's Refugees 1997-98, A Humanitarian Agenda, at. 1 - 2 (1998).

4. Ibid., at p. 2. The UNHCR acknowledges that this figure is highly speculative, given the absence of an agreed definition of 'forced displacement' and the difficulty of collecting accurate statistics on uprooted populations. The nominal figure of 50 million includes around 22 million people of direct concern to the UNHCR, an additional 20 million internally displaced people for whom the organization has no responsibility, and around three million Palestinian refugees who are assisted by the United Nations Relief and Works Agency for Palestine Refugees in the Near East.

5. United Nations High Commissioner for Refugees, Populations of Concern to UNHCR - 1997 Statistical Overview (1997).

6. Ibid.

7. From 1988 to 1997 , the refugee population of Africa decreased from 4.6 million to 3.5 million. In Asia, the figure went from 6.8 million to 4.8 million. (Populations of Concern to UNHCR - 1997 Statistical Overview, supra).

8. Convention relating to the Status of Refugees, 189 U.N.T.S. 2545, entered into force on April 22, 1954.

9. Hathaway, James C. , The Law of Refugee Status, at 8 (1991).

10. The State of the World's Refugees 1997-98, supra, at 48 .

11. Justice, Immigration Law Practitioners' Association, Asylum Rights Campaign, Providing Protection: Toward Fair and Effective Asylum Procedures, (1997), at 21.

12. Globally, Thoroughly and Effectively, supra note 1 , at 11 .

13. UNHCR. The State of the World's Refugees 1997-98, supra note 3 , at 33 .
14. Ibid., at 120.

15. U.S. Committee for Refugees. World Wide Refugee Information: Whoare Internally Displaced Persons?, from USCR website http:/ /www.refugees.org (1999).

16. UNHCR. The State of the World's Refugees 1997-98, supra at 105.

17. Newland, Kathleen. The Decade in Review, U.S. Committee for Refugees, (1999) at 4.

18. Ibid., at 11.

19. The State of the World's Refugees $1997-$ 98 , supra, at 34 .

20. Ibid., at 14 .

21. Ibid., at 15 .

22. Ibid., at 16 .

23. Ibid., at 16 .

24. Ibid., at 18-19.

25. Hathaway, James C., The Law of Refugee Status, supra, at 125.

26. Amnesty International, Refugees: Human Rights Have No Borders, ACT 34/03/97 at 4 (1997).

27. One reason that the conflicts in Bosnia and Kosovo have drawn so much attention is that they are obvious exceptions to this rule.

28. Lawyers Committee for Human Rights, The UNHCR at 40: Refugee Protection at the Crossroads, at 15 (1991).

29. Ibid, at 16

30. Ibid.

31. Ibid

32. Amnesty International. Refugees: Human Rights Have No Borders, supra, at p. 55. In 1992, after the war started in BosniaHerzegovina, large numbers of people were trying to escape conditions of generalized violence as well as torture, rape, and politicalkillings. That same year, nearly all Western European countries imposed a visa requirement on citizens of BosniaHerzegovina. See also UNHCR. The State of the World's Refugees , 1997-98, at 191.

33. Ibid, at 55. See also UNHCR. The State of the World's Refugees 1997-98, at 191.

34. Ibid, at 55. See also UNHCR. The State of the World's Refugees 1997-98, at 191.

35. Ibid, at 55. See also UNHCR. The State of the World's Refugees 1997-98, at 191. The most striking example of interdiction at sea in recent years was in June 1992, when the United States intercepted Haitian boat people at sea and summarily returned them, without any examination of their asylum claims. Cubans and Albanians have also been subjected to interdictions at sea. 
36. Ibid, at 74. See also UNHCR. The State of the World's Refugees 1997-98, at 192-193.

37. Ibid, at 58.

38. Ibid, at 73. See also UNHCR The State of the World's Refugees 1997-98, at 191-192.

39. Ibid, at 63. See also UNHCR. The State of the World's Refugees 1997-98, at 194.

40. Ibid, at 51 .

41. UNHCR. The State of the World's Refugees, supra, at 184.

42. Ibid, at 183 .

43. European Council of Refugees and EXiles, Position ofECRE on sharing the responsibility: protecting refugees and displaced persons in the context of large-scale arrivals, ECRE, London (1996), paragraph 14.

44. The State of the Worlds Refugees 1997-98, supra, at 198.

45. Amnesty International, Refugees: Human Rights Have No Borders, supra, at 60.

46. Ibid, at 58.

47. Ibid.

48. Ibid, at 58-59.

49. Conclusion 44 of the UNHCR Executive Committee.
So. Amnesty International, Refugees: Human Rights Have No Borders, supra, at 62.

51. Ibid, at 47.

52.Ward v. Canada (Minister of Employment \& Immigration) (1993), 103 D.L.R. (4th) 1 (S.c.q

53. UNHCR. The State of the World's Refugees 1997-98, supra at 194.

54 .'NoteonInternational Protection', UNHCR Executive Committee document no. AI AC96/830, September 1994.

55. UNHCR. The State of the World's Refugees 1997-98, supra at 199.

56. Ibid, at 199

57. Newland, Kathleen, The Decade in Review, supra, at 4.

58. Ibid, at 199- 200.

59. Ibid, at 209.

60. Newland, Kathleen. The Decade in Review, supra, at 7.

61. Convention relating to the Status of Refugees, supra, Article $1 \mathrm{C}$.

62. United Nations High Commissioner for Refugees. Handbook on Procedures and
Criteria for Determining Refugee Status (1979).

Geneva: Office of the United Nations High Commissioner for Refugees, paragraph 112.

63. UNHCR The Stateofthe Worlds Refugees 199798 , at 62

64. Ibid.

65. Ibid.

66. Ibid.

67. Ibid, at 65 .

68. Ibid.

69. Amnesty International. Refugees: Human Rights Have No Borders, supra, at 22.

70. UNHCR. The State of the World's Refugees 1997-98, supra, at 65.

71. Newland, Kathleen. The Decade in Review, supra, at 3 .

72. UNHCR. The State of the World's Refugees 1997-98, supra, at 68.

73. Ibid, at 69.

74. Newland, Kathleen. The Decade in Review, supra, at 7 .

75. Ibid.

76. Ibid, at 71 .

77. Ibid, at 77 .

78. Ibid, at 203. o

\section{The upcoming issues of Refuge:}

- Religious Refugees

- Health Issues Affecting Displaced Populations

- Challenges in Refugee Service Delivery

- Refugee Return

-The Other Side of the Equation: North American Trafficking in Women and Children

and a special issue on

- East Timor

(C) Michael Bossin, 1999. This open-access work is licensed under a Creative Commons Attribution-NonCommercial 4.0 International License, which permits use, reproduction and distribution in any medium for non-commercial purposes, provided the original author(s) are credited and the original publication in Refuge: Canada's Journal on Refugees is cited 